\title{
The Influence of CEO Compensation on Disclosure of Related Party Transactions with Corporate Governance as a Moderate Variable
}

\author{
Ratna Dewi Anggraini ${ }^{1 *}$, Evy Rahman Utami ${ }^{2}$ \\ 1,2 Department of Accounting, Faculty of Economics and Business, Universitas Muhammadiyah Yogyakarta, Yogyakarta, \\ Indonesia \\ *Corresponding author, Email: ratna.dewi.feb17@mail.umy.ac.id
}

\begin{abstract}
This study analyzes the effect of executive director (CEO) compensation on disclosure of related party transactions moderated by corporate governance. The samples used in this study were non-financial companies listed on the Indonesia Stock Exchange in 2017-2019. This study employed the purposive sampling method. The total data observations in this study were 1116 data from non-financial companies. The analytical tools utilized in this study were multiple linear regression analysis and the subgroup method for the moderating variable. The results of this study revealed that executive director compensation had a positive effect on disclosure of related party transactions, CEO duality had a positive effect on disclosure of related party transactions, and CEO duality moderated the positive effect of executive director compensation on disclosure of related party transactions.
\end{abstract}

Keywords: Executive director compensation, disclosure of related party transaction, corporate governance, CEO duality.

\section{INTRODUCTION}

For decades, related party transactions have become the center of attention for stakeholders ${ }^{1}$ worldwide [1]. Feleag \& Neac (2016) explained that related party transactions gave rise to a number of regulations, such as the American Congress, which published the Sarbanes-Oxley Act after the financial scandals of several large companies in the world (e.g., Enron, Arthur Andersen, WorldCom, and others). In Indonesia, in 2019, Sugianto (2019) mentioned that investors from PT. Tiga Pilar Sejahtera Food Tbk. found irregularities in the 2017 financial statements of PT. Tiga Pilar Sejahtera Food Tbk (AISA). Investors then asked PT. Ernst \& Young Indonesia to investigate the 2017 financial statements of PT. Tiga Pilar Sejahtera Food Tbk (AISA). The results of the investigation found that there was a flow of funds amounting to IDR 1.78 trillion through various schemes from the AISA Group to parties suspected of being affiliated with the old management of AISA. Therefore, the stakeholders began to consider the disclosure of related party transactions in investment considerations.

For this reason, this study aimed to investigate the effect of CEO compensation ${ }^{2}$ and CEO duality ${ }^{3}$ on the disclosure of related party transactions. In addition, the study also analyzes CEO duality, which moderates the effect of the president

\footnotetext{
${ }^{1}$ These stakeholders include a group of investors, regulators, academics, management, and so on.

${ }^{2}$ Indonesia implements a two-tier system, where the Chief Executive

Officer (CEO) is known as the president director who serves as the executive board of the company.
}

director's compensation on the disclosure of related party transactions.

Empirical studies of related party transaction disclosures have increased in several countries, such as Brazil, China, Malaysia, and Taiwan, after the financial scandal in the U.S., as explained by previous studies [4]-[11]. Alves and Leal (2016), Balsam (2017), Hu and Guang (2010), Rahmat et al. (2019), Shang et al. (2020), Wang (2014) explained that the president director's compensation had a positive effect on the disclosure of related party transaction. Balsam (2017), Hu and Guang (2010), Songhua et al. $(2009,2015)$ also asserted that CEO duality had a positive effect on the disclosure of related party transactions. However, in Indonesia, only a few studies are about the disclosure of related party transactions (Apriyani, 2016; Ferdi \& Rossieta, 2019; Helena \& Firmansyah, 2018; Izzaty \& Kurniawan, 2018). In addition, Apriyani (2016) uncovered that corporate governance did not affect the disclosure of related party transactions. Meanwhile, Ferdi \& Rossieta (2019) unveiled that institutional ownership positively affected the disclosure of related party transactions.

Disclosure of related party transactions is a form of presentation in financial statements regarding the transfer of services, resources, or obligations between related parties regardless of the price for the transfer [16]. Disclosure of

\footnotetext{
${ }^{3}$ The main director who also serves as the board of commissioners (supervisory board) in the company.
} 
related party transactions is one type of mandatory disclosure 4 (Badan Pengawas Pasar Modal dan Lembaga Keuangan, 2011). Related party transaction disclosure is also presented in Statement of Financial Accounting Standards 7 (revised 2010): disclosure of transactions with related parties adopted from International Accounting Standard 24: Related Party Disclosures. Elkelish (2017) and Sutiyok \& Rahmawati (2014) described that publicly traded companies need to perform disclosures - at least mandatory disclosures. The disclosure is to assist investors in making the right investment decisions. If companies do not perform disclosures, investors or users of financial statements will be incorrect in making investment decisions.

One of the factors that influence the disclosure of related party transactions is the compensation of the president director. The president director (CEO) is part of a related party within the company. The president director's compensation is shown from the total of the president director's basic salary and bonuses received by the president director, including stock options [20]. Alves and Leal (2016), Balsam (2017), Hu and Guang (2010), Shang et al. (2020), Wang (2014) showed that the compensation of the president director (CEO) was positively related to related party transactions. Besides, Balsam (2017) compared the relationship before and after issuing the Securities and Exchange Commission (SEC) regulations related to regulation No. 33-8732A between related party transactions and president director compensation. The impact of the Securities and Exchange Commission issuing regulation No. $33-8732 \mathrm{~A}$ is that many companies disclosed related party transactions carried out by directors with the board of commissioners, and the compensation they got was also getting bigger. Therefore, if the president director conducts related party transactions with their affiliates, the compensation received by the president director is also large, and vice versa.

Rahmat et al. (2019) elucidated that the compensation package given to the president director could reduce related party transaction conflicts. A related party transaction conflict occurs because of a direct or indirect transaction involving personal interests. For companies that conduct transactions with shareholders, the president director must disclose related party transactions. The president director then receives compensation in the form of a compensation package for disclosing related party transactions. However, Songhua et al. (2009) uncovered that the president director's compensation was negatively related to the disclosure of related party transactions. It is because the related party transaction is a scheme of the president director's compensation package mechanism. Therefore, the compensation received by the president director is low.

The second factor that affects the disclosure of related party transactions is the CEO duality. Songhua et al. (2009) explicated that the president director, who also serves as the board of commissioners, would increase the number of related party transactions. For example, the president director who serves as the board of commissioners in a different company conducts related party transactions with the parent entity in the form of purchases using the credit system; then, the balance in the debt's account increases. Thus, the number of related party transactions carried out is large. Nevertheless, the related party transaction carried out by the director creates a conflict of interest. Conflicts of interest will be reduced if the disclosure is made of transactions that occur related to related party transactions.

Moreover, Abdullatif et al. (2019) showed a negative relationship between CEO duality and related party transaction disclosure. Abdullatif et al. (2019) stated that the majority shareholder in the company has full control over the performance of the president director, regardless of whether the president director becomes the board of commissioners or not. The president director disclosed the related party transaction they carried out regardless of their role as the board of commissioners or not, but the disclosure was according to the request of the majority shareholder.

Meanwhile, Balsam (2017) revealed that corporate governance strengthened the positive relationship between the compensation of the president director and related party transactions. Balsam (2017) presented that before the Securities and Exchange Commission (SEC) issued regulations regarding the disclosure of related party transactions, it was found that corporate governance had weakened, which resulted in a positive relationship between the compensation of the president director and related party transactions. However, after the Securities and Exchange Commission (SEC) issued regulation No. 33-8732A related to the disclosure of related party transactions, the number of president directors conducting related party transactions has decreased, while the number of commissioners conducting related party transactions has increased. The concept of corporate governance used by Balsam (2017) is the duality of CEOs.

Further, this study is a replication of Rahmat et al.'s (2019). The differences between this study and the previous one are as follows. First, this study used samples from all companies listed on the Indonesia Stock Exchange, except for companies in the financial sector. Second, this study added the corporate governance variable as a moderating variable. In general, there are two corporate governance systems used by most countries, i.e., the one-tier system and the two-tier system [22]. The corporate governance system used in Indonesia is a two-tier system as described in Law No. 40 of 2007 concerning Limited Liability Companies. The concept of a two-tier system is that the company is run by two boards, i.e., the executive board that runs the company's internal affairs and the supervisory board that oversees the

${ }^{4}$ Mandatory disclosure is the disclosure of information required by an

authoritative institution-such as the Financial Services Authority.

Disclosure must be done so that investors avoid misleading information. 
performance of the executive board in the company. Law number 40 of 2007 concerning Limited Liability Companies states that the duality of CEOs in Indonesia may not directly involve the president director (executive board) who holds the role of the board of commissioners (supervisory board) in one company. However, it cannot be denied that the president director of company A also serves as the board of commissioners in company B. It can lead to the discovery of transactions between company A and company B, where the directors of company $\mathrm{A}$ and the board of commissioners in company $\mathrm{B}$ are the perpetrators of the transaction. Third, the period of this study was 2017-2019.

Therefore, it is hoped that this study can be used as development material and a reference to improve further academic research. For practitioners, this research is expected to pay attention to the disclosure of related party transactions under applicable regulations in Indonesia, namely PSAK 7.

\section{LITERATURE REVIEW AND HYPOTHESES DEVELOPMENT}

\subsection{Agency Theory}

Agency theory states that managers (as agents) convey information, not in line with the company's actual state to shareholders [23]. Agency theory explains the existence of a conflict of interest between the principal and the agent [23]. Managers who (as agents) do not carry out their duties following the interests of shareholders (as principals) create a conflict of interest [24]. Agency problems arise due to the separation of ownership and management.

Management as an agent has the responsibility to generate company profits, minimize company costs, and plan compensation. However, management does not convey all the information in line with the company's conditions [18],[23]. It is called information asymmetry. The information gap between management and stakeholders can provide an opportunity for management not to disclose related party transactions carried out by the president director. Ignat and Feleagă (2019) showed a positive relationship between disclosure of related party transactions and agency theory.

\subsection{Hypotheses Development}

\subsubsection{Influence of President Director's Compensation and Related Party Transaction Disclosure}

Agency theory affirms that agency costs can be reduced by providing compensation [25],[26]. Compensation is a vital part for agents (management). Agents (management) exchange their time to work toward the goals of the company and the principal. Therefore, the owner (principal) provides compensation to the agent. Compensation can be given in cash or in the form of equity [27].
Alves and Leal (2016), Balsam (2017), Hu and Guang (2010), Rahmat et al. (2019), Shang et al. (2020), and Wang (2014) explained that the president director's compensation was positively related to the disclosure of related party transaction. Alves and Leal (2016) elucidated that the president director who carried out related party transactions would receive higher compensation. If the president director conducts a related party transaction, a business claim, their compensation will be even greater. The amount of compensation for the president director is followed by the number of related party transactions. Related party transaction also influences the company's statement of financial position and income statement. The president director who conducts related party transactions will yield profit, and the compensation received by the president director is also large. However, large compensation creates a conflict of interest between the principal and agent. To reduce the conflict of interest, the company needs to disclose related party transactions carried out by the president director. The higher the compensation received by the president director, the higher the company's level of disclosure of related party transactions. Based on this statement, the first hypothesis can be derived as follows:

H1: The president director's compensation has a positive influence on related party transaction disclosure.

\subsubsection{Influence of CEO Duality and Related Party Transaction Disclosure}

One of the concepts of corporate governance is CEO duality. Waheed and Malik (2019) explicated that the duality of the CEO is shown from the president director (CEO), who acts as the manager of the company and as the board of commissioners (company supervisor). In this case, stakeholders appoint someone to oversee the company's activities carried out by the president director. It is done to prevent management from taking actions according to their interests, ignoring stakeholders' interests. If the board of commissioners of a company appointed is a president director in another company, it will cause a conflict of interest between stakeholders and management [29].

Balsam (2017), Hu and Guang (2010), and Songhua et al. (2009, 2015) explained that CEO duality was positively related to the disclosure of related party transactions. Songhua et al. (2015) also clarified that CEO duality was positively related to disclosing related party transactions. The board of commissioners who also serves as the president director will result in bad internal decisions [9]. It is because the board of commissioners ignores stakeholders' interests to achieve their interests, such as carrying out related party transactions without seeing whether the decision of the related party transaction is good. If the board of commissioners also acts as the president director, the size of the related party transaction is large. The high number of related party transactions will create a conflict of interest between management and stakeholders. 
For example, when a related party transaction occurs in the form of a sale with a credit system with a subsidiary, the balance of the income account (account in the income statement) and receivables from related parties (account on the statement of financial position) increases. Suppose A is the main director at $\mathrm{ABC}$ company, and $\mathrm{A}$ also serves as the board of commissioners in BCD company. In that case, A in $\mathrm{ABC}$ company conducts related party transactions at $\mathrm{BCD}$ company, and $\mathrm{A}$ in $\mathrm{BCD}$ company also carries out related party transaction in $\mathrm{ABC}$ companies, then the size of the related party transaction carried out by $\mathrm{A}$ is also large in each company. Both companies made huge profits. Thus, it will trigger a conflict between the stakeholders of the two companies and the management. To reduce the conflict, it is necessary to perform disclosure. Whether related to company operations or not, every activity that occurs in the company must be disclosed in the financial statements [26]. Based on the above statement, the second hypothesis can be derived as follows:

H2: CEO duality has a positive influence on related party transaction disclosure.

\subsubsection{Influence of CEO Duality between President Director's Compensation and Related Party Transaction Disclosure}

CEO duality is a corporate governance mechanism that combines the roles of company executives and company supervisors [30],[31]. The higher a person's role in a company, the higher the compensation and responsibilities. Therefore, the president director, who also serves as the board of commissioners, will receive a large amount of compensation. If the president director performs a dual role as the board of commissioners, it will cause conflict between management and stakeholders. Balsam (2017), Hu and Guang (2010), and Songhua et al. $(2009,2015)$ revealed a positive relationship between CEO duality and disclosure of related party transactions.

Balsam (2017) further argued that corporate governance strengthened the positive relationship between the compensation of the president director and the disclosure of related party transactions. The concept of corporate governance in this study is CEO duality. The results of their research also showed that there are differences between before and after the Securities and Exchange Commission (SEC) issued regulation No. 33-8732A regarding the disclosure of related party transactions. Prior to the issuance of the regulation, it was found that corporate governance had weakened, which resulted in many president directors conducting related party transactions without disclosing them in the financial statements. However, after the Securities and Exchange Commission (SEC) issued regulation No. 33$8732 \mathrm{~A}$, the president director showed a decrease in related party transaction activities carried out, while the size of related party transactions carried out by the board commissioners increased. Thus, this study explains that the board of commissioners performs a dual role, i.e., the board of commissioners acts as the main director and the supervisory board.

Furthermore, the compensation received by the president director will be even greater if they have two roles at once [5]. The two roles are the role of manager and supervisor. For example, if $\mathrm{A}$ is on the board of commissioners in company $\mathrm{X}$ and acts as a president director in company $\mathrm{B}$, then $\mathrm{A}$ is said to have $\mathrm{CEO}$ duality. If $\mathrm{A}$, as the main director in company $\mathrm{B}$, conducts related party transactions in company $\mathrm{X}$, and $\mathrm{A}$, as the board of commissioners in company $\mathrm{X}$, carries out related party transactions in company $\mathrm{B}$, then related party transactions carried out by A generate profits in the financial statements of the two companies. The transaction influences the profit generated in the income statement and the increase in assets in the statement of financial position in the two companies. Therefore, the compensation received by the president director will be even greater if they have two roles at once, i.e., being a board of commissioners in company $\mathrm{X}$ and directors in company $\mathrm{B}$.

If the president director, who also serves as the board of commissioners, conducts related party transactions and generates profits in the financial statements of the two companies, the compensation they receive will also be large. The greater the number of transactions carried out, the greater the profit generated by the company. In this regard, the amount of the company's profit will influence the compensation given to the president director and lead to conflicts of interest between stakeholders and company management. To reduce conflicts of interest between stakeholders and company management, companies need to disclose related party transactions. Based on the above statement, the third hypothesis can be derived as follows:

H3: CEO duality moderates the positive influence between president director's compensation on related party transaction disclosure.

\section{RESEARCH METHOD}

\subsection{Population and Sample}

This study used a quantitative approach with a hypothesistesting research design. The population in this study was companies listed on the Indonesia Stock Exchange. The sample in this study was companies listed on the Indonesia Stock Exchange, except for companies in the financial sector. The research period was from 2017 to 2019. The sampling technique of this research employed the purposive sampling method. The sampling criteria are shown in Table 1. 
Table 1 Research Sample

\begin{tabular}{|c|c|c|c|c|c|}
\hline \multirow[t]{2}{*}{ No. } & \multirow[t]{2}{*}{ DESCRIPTION } & \multicolumn{3}{|c|}{ RESEARCH PERIOD } & \multirow[t]{2}{*}{ TOTAL } \\
\hline & & 2017 & 2018 & 2019 & \\
\hline 1. & $\begin{array}{l}\text { Non-finance } \\
\text { companies } \\
\text { listed on the } \\
\text { Indonesia } \\
\text { Stock } \\
\text { Exchange } \\
\text { during } 2017 \text { - } \\
2019\end{array}$ & 467 & 521 & 571 & 1559 \\
\hline 2. & $\begin{array}{l}\text { Companies } \\
\text { that issue finan } \\
\text { cial statements }\end{array}$ & 467 & 521 & 532 & 1520 \\
\hline 3. & $\begin{array}{l}\text { Companies } \\
\text { that do } \\
\text { not disclose rel } \\
\text { ated party } \\
\text { transaction }\end{array}$ & (7) & (9) & (11) & (27) \\
\hline 4. & $\begin{array}{l}\text { Companies } \\
\text { that do not use } \\
\text { Rupiah as } \\
\text { the unit } \\
\text { of currency }\end{array}$ & (91) & (89) & (91) & (271) \\
\hline 5. & $\begin{array}{l}\text { Companies } \\
\text { that do } \\
\text { not disclose ke } \\
\text { y management } \\
\text { compensation }\end{array}$ & (41) & (37) & (28) & (106) \\
\hline \multicolumn{2}{|c|}{$\begin{array}{l}\text { Number } \\
\text { of companies that } \mathrm{m} \\
\text { eet the criteria }\end{array}$} & 328 & 386 & 402 & 1116 \\
\hline
\end{tabular}

Source: Secondary data processed in 2020

\subsection{Operational Variables}

The dependent variable in this study was the related party transaction disclosure. Meanwhile, the principal director's compensation and CEO duality were the independent variables. Then, CEO duality was the moderating variable. Table 2 describes the operational definition of each variable.
Table 2 Operational Definition of Variables

\begin{tabular}{|c|c|c|}
\hline VARIABLES & DEFINITION & MEASUREMENT \\
\hline $\begin{array}{l}\text { Related Party } \\
\text { Transaction } \\
\text { Disclosure }\end{array}$ & $\begin{array}{l}\text { Disclosure of } \\
\text { transactions } \\
\text { conducted by } \\
\text { the company } \\
\text { with related } \\
\text { entities such as } \\
\text { shareholders, } \\
\text { affiliated } \\
\text { companies, } \\
\text { members of the } \\
\text { board of } \\
\text { directors, and } \\
\text { other related } \\
\text { parties [2]. }\end{array}$ & $\begin{array}{l}\text { Related } \\
\text { Transaction } \\
\text { Disclosure } \\
=\frac{n}{6} \times 100 \%\end{array}$ \\
\hline $\begin{array}{l}\text { CEO } \\
\text { Compensation }\end{array}$ & $\begin{array}{l}\text { The total } \\
\text { amount of } \\
\text { compensation } \\
\text { received by the } \\
\text { president } \\
\text { director, } \\
\text { including } \\
\text { salaries, } \\
\text { bonuses and } \\
\text { allowances [29]. }\end{array}$ & $\begin{array}{l}\text { Comp }=\text { Ln (total } \\
\text { compensation of the } \\
\text { president director in } \\
\text { cash) }\end{array}$ \\
\hline CEO Duality & $\begin{array}{l}\text { CEO who } \\
\text { served on the } \\
\text { board of } \\
\text { commissioners } \\
\text { in different } \\
\text { companies [29]. }\end{array}$ & $\begin{array}{l}\text { CEO duality is } \\
\text { measured using a } \\
\text { nominal scale, } \\
\text { where: } \\
1=\text { The CEO also } \\
\text { serves on the board } \\
\text { of commissioners } \\
0=\text { The CEO does } \\
\text { not serve on the } \\
\text { board } \\
\text { commissioners }\end{array}$ \\
\hline Leverage & $\begin{array}{l}\text { How many } \\
\text { assets are } \\
\text { financed by debt } \\
\text { for the company } \\
{[21]}\end{array}$ & $\begin{array}{l}\text { Debt to Asset Ratio } \\
=\frac{\text { Total Utang }}{\text { Total Aset }}\end{array}$ \\
\hline Size & $\begin{array}{l}\text { The size of a } \\
\text { company is seen } \\
\text { from the total } \\
\text { assets [21]. }\end{array}$ & $\begin{array}{l}\text { Size } \\
\text { asset) }\end{array}$ \\
\hline
\end{tabular}

Source: Previous studies processed in 2020

\subsection{Analysis Techniques}

The data collection technique employed the documentation method. The data were taken from the annual financial statements and annual reports of non-financial companies listed on the Indonesia Stock Exchange during the 2017-2019 
period. Hypothesis testing was carried out using moderated regression analysis with the sub-group method.

Testing the president director's compensation and CEO duality on the disclosure of related party transactions utilized multiple linear regression analysis with the following equation model.

RPTDiscl $=a+b_{1}$ Comp $+b_{2}$ CEODual $+b_{3} L e v+b_{4}$ Size (1)

RPTDISCL $=a+b_{1}$ Comp $+b_{2}$ CEODual $+b_{3} L e v+b_{4}$ Size $+b_{5}$ Comp $*$ CEODual $+e$

The test of CEO duality moderation on the influence of the president director's compensation on the related party transaction disclosure with the above equation was not conducted. It was because the CEO duality (as a moderating variable) was in the form of a dummy variable. The dummy variable was used to categorize qualitative data in the form of a nominal scale, such as code 1 for the CEO who serves as the board of commissioners and code 0 for the CEO who does not serve on the board of commissioners. When dummy variables are interacted, it will result in errors in the interpretation of the results of the hypothesis [32].

It is better to test the CEO duality moderation on the influence of the president director's compensation on related party transaction disclosures using the sub-group method [32]. Regression analysis of the moderating variable with the sub-group method was carried out by dividing the sample into two categories based on the hypothesized moderating variable.

Below are the regression equation models for the dummy category (CEO duality):

RPTDISCL $=a+b_{1}$ Comp $+b_{2}$ CEODual $(D=C E O$ is Not in the Board of Commissioners $)+b_{3} L e v+b_{4}$ Size +

RPTDISCL $=a+b_{1}$ Comp $+b_{2}$ CEODual $(D=C E O$ is in the Board of Commissioners $)+b_{3}$ Lev $+b_{4}$ Size +

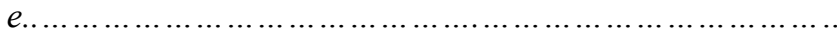

\section{RESULTS AND DISCUSSION}

\subsection{Descriptive Analysis}

The descriptive statistical analysis in Table 3 shows that the variable of disclosure of related party transactions had a mean of 0.832 with a standard deviation of 0.129 . It indicates that of the 1116 total data owned, the average disclosure of related party transactions reached $83.2 \%$. Then, the variable of the main director's compensation had a mean value of 22.94 with a standard deviation of 1.58 . It denotes that, on average, the sampled companies were companies with high compensation. Besides, the variable of CEO duality had a mean value of 0.37 with a standard deviation of 0.484 . It signifies that $37 \%$ of the company's CEOs held concurrent positions on the board of commissioners. Meanwhile, the leverage variable had a mean value of 0.48473 and a standard deviation of 0.32 . It further shows that $48.47 \%$ of the total sample were companies with high leverage. At last, the firm size variable had a mean value of 28.37 with a standard deviation of 1.72 . It means that $2837 \%$ of the total sampled companies were large companies.

Table 3 Descriptive Statistical Analysis

\begin{tabular}{|l|l|l|l|l|l|}
\hline & N & Min. & Max. & $\begin{array}{l}\text { Std. } \\
\text { Deviati } \\
\text { on }\end{array}$ & Mean \\
\hline $\begin{array}{l}\text { Related } \\
\text { Party } \\
\text { Transactio } \\
\mathbf{n} \\
\text { Disclosur } \\
\mathbf{e}\end{array}$ & 1116 & 0.333 & 1.000 & 0.1286 & 0.8324 \\
\hline $\begin{array}{l}\text { CEO } \\
\text { Compens } \\
\text { ation }\end{array}$ & 1116 & 16.52 & 33.52 & 1.5823 & 22.938 \\
\hline $\begin{array}{l}\text { CEO } \\
\text { Duality }\end{array}$ & 1116 & 0 & 1 & 0.484 & 0.37 \\
\hline Leverage & 1116 & 0.006 & 3.740 & 0.3253 & 0.4847 \\
\hline Size & 1116 & 22.92 & 33.49 & 1.7210 & 28.372 \\
\hline Valid N & 1116 & & & & \\
\hline
\end{tabular}

Source: Secondary data processed in 2020

\subsection{Testing Hypothesis 1: President Director's Compensation has a Positive Influence on Related Party Transaction Disclosure.}

The results of testing hypothesis 1 in this study are presented in Table 4

Table 4 The Results of Hypothesis 1 and 2 Tests

\begin{tabular}{|c|c|r|r|}
\hline \multicolumn{2}{|c|}{ Model } & $\begin{array}{c}\text { Unstandardized } \\
\text { Coefficients }\end{array}$ & \\
\cline { 3 - 4 } \multicolumn{2}{|c|}{} & B & Sig. \\
\hline 1 & (Constant) & 0.491 & 0.000 \\
\cline { 2 - 4 } & CEO Compensation & 0.015 & 0.000 \\
\cline { 2 - 4 } & CEO Duality & 0.017 & 0.028 \\
\cline { 2 - 4 } & Leverage & 0.000 & 0.886 \\
\cline { 2 - 4 } & Size & 0.000 & 0.877 \\
\hline
\end{tabular}

Source: Secondary data processed in 2020

The hypothesis can be said to be accepted if the value of sig. $<0.05$. In table 4 , CEO compensation had a significance value of $0.000<0.05$ and a positive $B$ value. Therefore, it can be said that hypothesis 1 was accepted. It 
means that CEO compensation had a positive influence on related party transaction disclosure. This study is in line with agency theory, where the compensation received by the president director will cause a conflict of interest between the principal and the agent. The agent is the party that manages the company, while the principal is the company's owner. The goal of the stakeholders (principal) is that the company generates profit and the purpose of the company's establishment [33]. To achieve these goals, management (agents) must align management goals with stakeholder goals [23]. Management who has managed the company in accordance with stakeholder objectives will receive compensation. However, the amount of compensation given creates a conflict between stakeholders and management. Therefore, disclosure of compensation is made to prevent these conflicts.

Moreover, related party transactions can result in profit or loss for the company. If the president director conducts related party transactions and records profits in the company's financial statements, the compensation received by the president director is also large. Alves and Leal (2016) explained that the compensation received by the president director depends on the size of the responsibility received. If the president director carries out a related party transaction, their compensation will also increase. This compensation creates conflicts between stakeholders and management. To reduce conflicts due to the amount of compensation received by the president director, a disclosure is made regarding the amount of compensation.

The results of this study are in line with the previous studies [4]-[6], [8], [10], [11], which gave the same conclusion, i.e., that the compensation of the president director had a positive influence on related party transaction disclosure. Rahmat et al. (2019) also explicated that the compensation package received by the president director reduced the related party transaction conflicts they did but increased the related party transaction disclosure. It is because the president directors receive compensation that requires them to disclose related party transactions.

\subsection{Testing Hypothesis 2: CEO Duality has a Positive Influence on Related Party Transaction Disclosure.}

The hypothesis 2 testing results in this study are shown in Table 4. In table 4, CEO duality had a sig. value of 0.028 , so it can be concluded that hypothesis 2 was accepted. It denotes that CEO duality had a positive influence on related party transaction disclosure. Abbas et al. (2018) mentioned that the duality of the CEO is shown from the president director who acts as the manager of the company and serves as the board of commissioners or supervisors for the activities carried out by the president director in different companies. In this case, agency theory explains the conflicts that occur between management and stakeholders [23]. As owners of the company, stakeholders choose someone to supervise the company's activities carried out by the president director. The selection of the board of commissioners is conducted to prevent management actions that ignore stakeholders' interests.

Further, Songhua et al. (2009) stated that the board of commissioners is elected by the majority shareholder at the General Meeting of Shareholders. The majority shareholder elects a board of commissioners to oversee every activity carried out by management. However, the majority shareholder appoints a board of commissioners who can help them to achieve their interests. Therefore, the selected board of commissioners is the president director. The president director is directly involved with the company's activities, where the president director knows everything in the company, such as the best way to make a profit and so on, to help stakeholders achieve their goals. If the board of commissioners appointed by the stakeholders is the president director, this will trigger a conflict of interest. For example, B is the president director at company $\mathrm{AC}$, and $\mathrm{B}$ is also a commissioner at company $\mathrm{BC}$, then $\mathrm{B}$ at company $\mathrm{AC}$ conducts related party transactions with company $\mathrm{BC}$, and $\mathrm{B}$ in company $\mathrm{BC}$ also conducts related party transactions with its shareholders. In that case, the amount of related party transactions that B performed is also large. The number of related party transactions will influence the balance in the accounts in the company's financial statements [16].

It can also trigger conflicts between management and stakeholders. Thus, to reduce the conflict, the company needs to disclose all activities that occur in the company, both those related to company operations - such as related party transactions - or those unrelated to company operations. The results of this study support previous studies [5], [7]-[9], which explained that CEO duality had a positive influence on the related party transaction disclosure.

\subsection{Testing Hypothesis 3: CEO Duality Moderates the Positive Influence between President Director's Compensation on Related Party Transaction Disclosure.}

Moderation testing using the sub-group method was carried out with the Chow-test. From the results of this Chowtest, it can be concluded whether the moderating variable moderates an influence between independent and dependent variables [32]. The results of the Chow-test in this study are displayed in Table 5.

Table 5 Chow-Test Results

\begin{tabular}{|c|r|}
\hline F-count & F-table \\
\hline 256.152434 & 2.37 \\
\hline
\end{tabular}

Sources: Secondary data processed in 2020

If the value of F-count > F-table, then the moderating variable moderates the influence of the independent and dependent variables [32]. In this study, because the value of F-count (256.152434) > F-table (2.37), it can be concluded that CEO duality moderated the influence of CEO 
compensation on related party transaction disclosure. In other words, hypothesis 3 was accepted. The duality of the CEO is shown by the president director, who also serves as a board of commissioners in different companies. In this regard, agency theory describes the conflict of interest between management as an agent and stakeholders as principals [23]. Management is a party contracted by stakeholders to achieve their goals [35]. Therefore, the management must account for their work for the stakeholders. The agent agrees with the principal to perform the tasks assigned by the principal, and then the principal makes a contract to provide compensation to the agent. Nevertheless, the amount of compensation received by the management will trigger a conflict between the agent and the principal [18], [23]. To prevent conflicts of interest, it is necessary to disclose information related to the remuneration received by management in the financial statements.

This study indicates that CEO duality moderated the positive influence of the president director's compensation on related party transaction disclosure. Based on the adjusted $\mathrm{R}$ square value for equation (1), before moderation was $3.7 \%$; for equation (2.a) category 0 , it was $5 \%$. Besides, the adjusted $\mathrm{R}$ square value for equation (2.b) category 1 was $0.1 \%$. It denotes an increase in the adjusted $\mathrm{R}$ square value. The Chow-test results were then used to conclude from the moderation hypothesis test results on the subgroup method. The results of the Chow-test showed that CEO duality moderated the positive influence of the president director's compensation on the disclosure of related party transactions. Companies that were the samples of this study whose main director also served as a board of commissioners in different companies were only $37 \%$. Therefore, the CEO duality, which moderated the influence of the president director's compensation on the related party transaction disclosure, was only in companies where the chief director performed the dual role.

Moreover, the results of this study align with agency theory, which puts forward that if the president director carries out a related party transaction - this transaction results in the company making a profit - the higher the compensation they receive. Let alone if the president director is also the board of commissioners in a different company and conducts related party transactions between the two companies [5]. For example, $\mathrm{A}$ is a member of the board of commissioners of $\mathrm{JK}$ company and serves as the president director of JH company, then $\mathrm{A}$ as a commissioner of JK company deals with the president director of JH company. The transaction makes both the company's financial statements print a profit. Because the two companies are making a profit, the compensation received by $\mathrm{A}$ is also getting bigger. This compensation can also lead to conflict between management and stakeholders. Meanwhile, this conflict can be reduced by disclosing information related to remuneration in the financial statements. The results of this study agree with Balsam (2017), who stated that CEO duality moderated the positive influence of president director's compensation on related party transaction disclosure.

\section{CONCLUSION}

The study results revealed that: (1) The main director's compensation had a positive influence on the related party transaction disclosure; (2) CEO duality had a positive influence on the related party transaction disclosure; (3) CEO duality moderated the influence of the president director's compensation on the related party transaction disclosure.

However, the limitations of this study are that this study only used two independent variables: the main director's compensation and the corporate governance, and one moderating variable: the corporate governance. Therefore, this study has not explained the factors influencing the related party transaction disclosure. In addition, the research period was only from 2017-2019. Further research suggests using other variables besides the president director's compensation and CEO duality and utilizing the latest year range for the period.

\section{REFERENCES}

[1] I. Ignat and L. Feleagă, "Research regarding the issues of the arm's length principle mentioned by I.A.S. 24," Econ. Res. Istraz. , vol. 32, no. 1, pp. 3034-3051, 2019, doi: 10.1080/1331677X.2019.1655659.

[2] L. Feleag and I. Neac, "Disclosure of related party transactions and information regarding transfer pricing by the companies listed on Bucharest Stock Exchange," J. Account. Manag. Inf. Syst., vol. 15, no. 4, pp. 785-809, 2016.

[3] D. Sugianto, "Kasus Produsen Taro Bisa Bikin Perusahaan RI Takut Investor Asing," 2019. https://finance.detik.com/bursadan-valas/d-4496848/kasus-produsen-taro-bisa-bikinperusahaan-ri-takut-investor-asing.

[4] M. B. Alves and R. P. C. Leal, "Board characteristics and compensation in Brazilian listed companies," Int. J. Discl. Gov., vol. 13, no. 4, pp. 309-328, 2016, doi: 10.1057/s41310016-0013-4.

[5] S. Balsam, "Related party transactions, corporate governance and CEO compensation," 2017, doi: 10.1111/jbfa.12245.

[6] X. Shang, C. Luo, and Q. Wen, "Do Chinese Executives Reward for Luck?," Econ. Model., 2020, doi: 10.1016/j.econmod.2020.01.012.

[7] H. Songhua, S. Yanqin, and X. Yuehua, "Determinants of related-party transactions: Evidence from China' $\mathrm{s}$ listed companies during," vol. 3, no. 2, pp. 190-206, 2009, doi: 10.1007/s11782-009-0010-6.

[8] S. Hu and L. Guang, "An empirical study on cross-border related party transactions of China's listed companies," pp. 14, 2010.

[9] H. Songhua, L. Guang, X. Yue-hua, and X. Fan, "Effects of Internal Governance Factors on Cross-Border-Related Party Transactions of Chinese Companies," Emerg. Mark. Financ. Trade, vol. 88, no. 1, pp. 58-73, 2015, doi: 10.2753/REE1540496X4801S105.

[10] M. M. Rahmat, N. S. M. Ghazali, and N. Nordin, "Are executive directors paid enough? Evidence from conflicting related-party transactions," Int. J. Econ. Manag., vol. 13, no. 
1, pp. 111-124, 2019.

[11] M. Wang, "Idiosyncratic volatility, executive compensation and corporate governance: examination of the direct and moderate effects," no. 1, 2014, doi: 10.1007/s11846-0140143-7.

[12] R. Helena and A. Firmansyah, "Pengungkapan Pihak-Pihak Berelasi pada Perusahaan-Perusahaan Salim Group yang Terdaftar di Bursa Efek Indonesia," J. Online Insa. Akuntan, vol. 3, no. 2, pp. 185-196, 2018, [Online]. Available: www.kemenkeu.go.id,

[13] K. N. Izzaty and P. C. Kurniawan, "Pengaruh Kinerja Keuangan, Struktur Kepemilikan dan Corporate Governance Terhadap Tingkat Kepatuhan Pengungkapan Transaksi Pihak Berelasi Pasca Konvergensi IFRS," JWEM STIE Mikroskil, vol. 8, no. 2, pp. 215-228, 2018.

[14] F. Ferdi and H. Rossieta, "The Effect of Institutional Ownership on Disclosure of Related Party Transactions: Empirical Evidence from Indonesian Publicly Listed Companies," 1st Asia Pacific Bus. Econ. Conf. (APBEC 2018), vol. 89, pp. 313-317, 2019, doi: 10.2991/apbec-18.2019.41.

[15] H. W. Apriyani, "Pengaruh Corporate Governance Dan Karakteristik Perusahaan Terhadap Luas Pengungkapan Transaksi Pihak Berelasi Di Indonesia," J. Akunt. Indones., vol. 4, no. 1, pp. 36-50, 2016, doi: 10.30659/jai.4.1.36-50.

[16] D. S. A. K. I. PSAK, "Pengungkapan pihak-pihak berelasi," vol. 7, no. 1, pp. 1-12, 2015.

[17] K. K. R. I. Badan Pengawas Pasar Modal Dan Lembaga Keuangan, “KEP-698/BL/2011,” 2011.

[18] W. W. Elkelish, "IFRS related party transactions disclosure and firm valuation in the United Arab Emirates emerging market," J. Account. Emerg. Econ., vol. 7, no. 2, pp. 173-189, 2017, doi: 10.1108/jaee-05-2015-0035

[19] Sutiyok and E. Rahmawati, "Pengaruh Mekanisme Corporate Governance Terhadap Tingkat Kepatuhan Mandatory Disclosure Konvergensi Ifrs di Perbankan," J. Account. Invest., vol. 15, no. 2, pp. 151-162, 2014.

[20] M. J. Conyon and L. He, "Executive Compensation and Corporate Fraud in China," J. Bus. Ethics, no. December 2014, pp. 669-691, 2016, doi: 10.1007/s10551-014-2390-6.

[21] M. Abdullatif, M. Alhadab, and I. Mansour, "Determinants of Related Party Transactions in Jordan: Financial and Governance Factors," Australas. Accounting, Bus. Financ. J., vol. 13, no. 1, pp. 76-89, 2019, doi: 10.14453/aabfj.v13i1.4.

[22] R. Rasyidah, "Perbandingan corporate governance dengan sistem one-tier board di Inggris dan AS terkait efektitififas pencegahan terjadinya fraud dalam korporasi," Glob. Policy, vol. 1, no. 1, pp. 11-18, 2013.

[23] C. M. Jensen and W. H. Meckling, "Theory of The Firm: Managerial Behavior, Agency Costs and Ownership Structure," J. financ. econ., no. 3, pp. 305-360, 1976, doi: $10.1177 / 0018726718812602$.

[24] E. Y. Tyas and I. Utami, "Trust in leadership and incentives: Experimental study of whistleblowing intention," J. Akunt. Audit. Indones., vol. 24, no. 1, pp. 43-54, 2020, doi: 10.20885/jaai.vol24.iss1.art5.

[25] Z. S. Maigoshi, R. A. Latif, and H. Kamardin, "Earnings management: A case of related party transactions," Int. J. Econ. Financ. Issues, vol. 6, no. 7Special Issue, pp. 51-55, 2016.

[26] M. Duwu, S. Daat, and H. Andriati, "Pengaruh Biological Asset Intensity, Ukuran perusahaan, Konsentrasi Kepemilikan, Jenis KAP, dan Profitabilitas terhadap Biological Asset Disclosure," J. Akunt. dan Keuang. Drh., vol. 13, no. 2, pp. 56-75, 2018, doi: $10.1017 / \mathrm{CBO} 9781107415324.004$

[27] O. Hope, "Director compensation and related party transactions," 2019.

[28] A. Waheed and Q. A. Malik, "Board characteristics, ownership concentration and firms' performance: A contingent theoretical based approach," South Asian J. Bus. Stud., vol. 8, no. 2, pp. 146-165, 2019, doi: 10.1108/SAJBS03-2018-0031.

[29] E. Rescigno, "Relationship Between Chief Executive Officer Compensation, Duality, and Return on Equity," 2018.

[30] S. S. Gaur, "Ownership concentration, board characteristics and firm performance A contingency framework," vol. 53, no. 5, pp. 911-931, 2015, doi: 10.1108/MD-08-2014-0519.

[31] M. T. Moore, "Corporate governance, pay equity, and the limitations of agency theory," Curr. Leg. Probl., vol. 68, no. 1, pp. 431-464, 2015, doi: 10.1093/clp/cuv002.

[32] S. Risna, Y. Desi, and P. Ika, "Pemodelan Regresi Variabel Moderasi Dengan Metode Sub-Group," J. Eksponensial, vol. 6, no. 2, pp. 153-162, 2015.

[33] Y. Yeh, P. Shu, T. Lee, and Y. Su, "Non-Tradable Share Reform and Corporate Governance in the Chinese Stock Market," vol. 17, no. 4, pp. 457-475, 2009, doi: 10.1111/j.1467-8683.2009.00754.x.

[34] M. Abbas, S. Ullah Qureshi, M. Munir Ahmed, and M. Rizwan, "Corporate Governance and Dividend Payout Policy: Mediating Role of Leverage," Pakistan J. Soc. Sci., vol. 38, no. 1, pp. 62-86, 2018.

[35] N. A. N. N. Azman, F. I. Roslan, N. A. R. Hamzah, N. A. H M. Azmi, and N. F. A. Manaf, "The Effect of Firm and Corporate Governance Characteristics towards Online CSR Disclosure in Malaysia.," Glob. Bus. Manag. Res., vol. 10, no. 3, pp. 75-84, 2018, [Online]. Available: http://search.ebscohost.com/login.aspx?direct=true \&db=buh $\& \mathrm{AN}=133618102 \&$ site $=$ ehost-live. 